العدد الثاني والأربعون

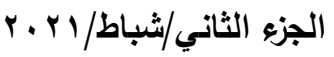
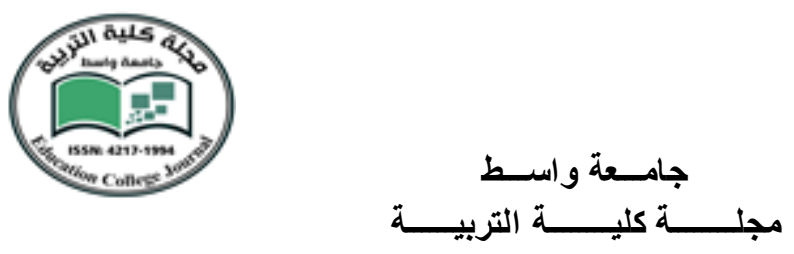

A Study of Manipulation in Some

Selected Reports

${ }^{1}$ Alia' Jawad Almagsosi (MA candidate) \& Khalida H. Alghezzy (PH.D)

Asst. prof

College of Education for Humanities, University of Wasit, Iraq alyaaj569@gmail.com

\title{
Abstract
}

The current study is concerned with Manipulation as one of the important linguistic phenomena. Manipulation is a linguistic term with great creative potential that is first and foremost topical in the framework of the theory of linguistic manipulation. The widespread and blurry semantic filed of 'manipulation' includes the key elements like the speaker's negative and covert intention that is not evident for the listener.

The study aims at showing the concept of manipulation, its types and the use of manipulation in two reports concerning Golan Heights presented by CNN and RT.

The study adopts an eclectic model of analysis, Malyuga and et al, 2018, Issers, 2008 and Leontive, 1999 . The study concludes that manipulation is divided into five main types according to: the nature of subject-object interaction, awareness of verbal actions, the type of speech acts, nature of recipient's response in addition to the objective focus of manipulative efforts. There is a great similarity in the use of manipulation and its types in both reports. The only difference between them is in terms of the 'nature of subject-object interaction' that CNN uses direct $100 \%$ while RT uses direct and indirect manipulation equally $50 \%$.

Keywords: Manipulation, direct and indirect manipulation, language, covert and negative intention.

*A Critical Discourse Analysis of Donald Trump's Claims in the Golan Heights Crisis in Media 
العدد الثاني والأربعون

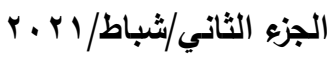

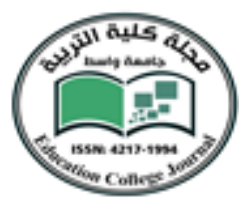

المستخلص

الدراسة الحالية تعنى بالتلاعب اللغوي كأحد الظواهر اللغوية المهمة. التلاعب هو "مصطلح لغوي يتمتع بإمكانيات إبداعية كبيرة ، وهو أولاً وقبل كل شيء موضوعي في إطار نظرية التلاعب اللغوي". يتضمن الحقل الدلالي الواسع الانتشار وغير الواضح لكلمة "التلاعب" العناصر الأساسية منل نية المتحدث "السلبية" والسرية "غير الواضحة للمستمع" شخصية التأثير • تهدف الدراسة إلى: عرض مفهوم التلاعب وأنواعه وإظهار استخدام التلاعب في ثقريرين عن مرتفعات الجولان قدمتهما CNN و RT الاخباريتين.

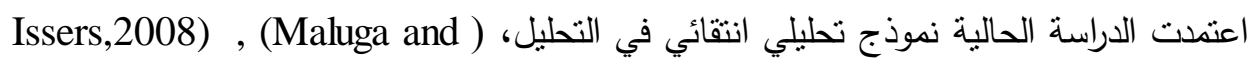
(et al,2018) و (Leontive, 1999). وخلصت الدراسة إلى أن التلاعب ينقسم إلى خمسة أنواع (لفاع رئيسية حسب: "طبيعة التفاعل بين الموضوع والثيء ، وإدراك الأفعال اللفظية ، ونوع أفعال الكلام وطبيعة استجابة المنلقي ، والتركيز الموضوعي لجهود التلاعب" وهناك تشابه CNN

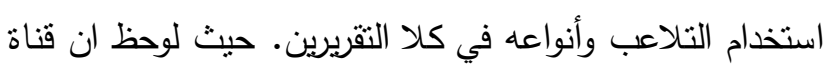

استخدمت التلاعب اللغوي المباشر بنسبة . . 1\% اما فيما يخص القناة فانها استخدمت التلاعب اللغوي المباشر وغير المباشر بنسبه . \% \%

الكلمات المفتاحية: التلاعب اللغوي، التلاعب اللغوي المباشر وغير المباشر، اللغة، الهذف الخفي

\section{Concept of Manipulation}

والسلبي.

Manipulation is a linguistic expression which has a vast innovative feasibility which is the initial and most important contemporary technique in the frame of linguistic manipulation theory. Semantic area of the concept manipulation which is broad and rather fuzzy involves essential elements such as the speaker's negative intention and hidden influence. Invisible and disguised level of linguistic data which is difficult to be detached from the real informative content is originated by the role of manipulation of discourse. More significance is given, relying on the nature of the utterance which is whether the utterance is directed to past or future, either to substantiation on the topical truth (i.e. whether the subject of the communication is related to something has already occurred) or to the pragmatic element, i.e. the speaker's directness whose speech is correlated with the future (Asya, 2017). 

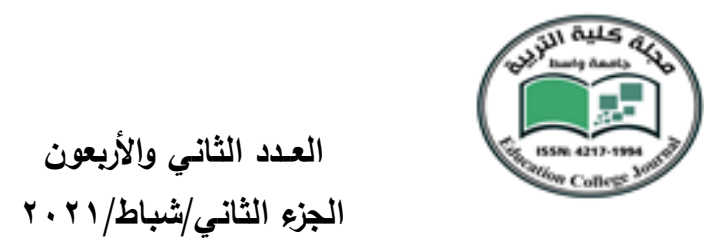

Since the receiver is often unable to understand the covert intentions behind the speaker's use of certain utterances, manipulation is provided. The specific intentionality is one of the main important elements in manipulative speech so one must examine such elements as (the aim of oral communication, logic motivation and explicit intention) in order to produce manipulation. Manipulation can be distinguished as a pragmatic aspect whose aims are attained with no obvious revelation of communicative intention. The utterance form which is chosen by the speaker does not include overt markers of his / her intention. It is clear that manipulation works in expanding the deception of the subjective reality by raising the level of the perception of information area which is inconvenient. As a result, manipulation is unfavorable psychological phenomenon in the society which exerts a destructive impact on the individuals as well as the entire society.

Pelz (1981) shows that the manipulation of some linguistic forms and structures implies beginning by the smallest and the most discrete segments or forms and ending in large linguistic entities. This is done clearly with the purpose of providing another means of deciding the speaker /hearer's attention into what is the subject and substance of the particular discourse in which the manipulation occurs.

Also, Pelz (1981) points out that manipulation of linguistic entities must be declared as a kind of foregrounding. Foregrounding can be explained as a "linguistic process in which some elements, such as words, phrases, sentences, stressing, intonations, or the like are given prominence or made more meaningfully significant by the communicator/language-user.

Blass (2002) explains that when manipulation is applied to manipulative discourse, it looks as a type of 'lexicalized metaphorical derivation.' It is like a strategy without it the speaker may not be capable of changing the receiver's principles and behavior. "Manipulation of an individual is directly related to applying constraints, in particular constraints that the individual is not aware of" (Blass, 2002:123). And these constraints work on the information treatment process and they are developed with more or less proficient and erudite strategies which aim of misleading the receiver in a way or another. As a result, the commitment of the receiver to the propositions carried by the discourse must be sincere. The addressee 

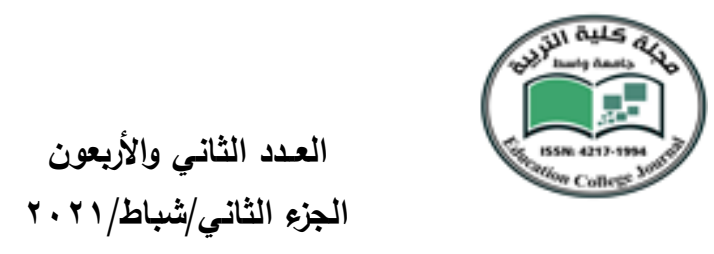

commitment must be sincere whereas the expressed propositions are in fact problematic at several levels. Additionally, hidden strategies are important as "obvious and brutal force cannot gain sincere commitment. Freedom of thought, or at least the illusion of it, is a necessary condition for manipulation" (Blass, 2002: 123).

\section{Manipulation and Deception}

As it is explained above that manipulation is a linguistic term with great creative potential that is first and foremost topical in the framework of the theory of linguistic manipulation. The widespread and blurry semantic concept of manipulation includes the key elements of the speaker's negative intention and covert, not evident for the listener and personality of influence. Functions of manipulation of discourse can create covert, disguised level of linguistic data which is not separated easily from virginally informational content. Basing on the utterance character "its orientation towards past or future", more prominence is devoted to either corroboration with objective reality "if the topic of interaction touches upon something that has already happened" or to the pragmatic issue "frankness of the speaker whose speech is associated with the future" (Beard, 2000:37).

Deception is a misleading for others deliberately, "willingly and/or with intent. It is - similar to the vast majority of deception theory and research established on the idea that deception is essentially intentional." However, "the proponents of the Information Manipulation Theory - (IMT) and Truth Default Theory (TDT) espouse functional definitions of deception and do not require a preconceived aim." (Levin and McCornack, 2014: 4),

According to Oesch (2016: 44), Deception is one of substantial features which "discriminates human beings from other creatures in the language." Some observers assume that the elementary task of the language from the biological sciences' point of view of is to parsimoniously deceive and manipulate rivals. In spite of a large amount of the theoretical and practical studies "with the social connecting theories for language functions, there are not considerable discussions for the apparent proof and debate for the deception hypothesis." Oesch adds that as it has been proposed through the investigation of the existing proof and debates of mankind behavior, studies of comparative animal behavior and the development of psychological 

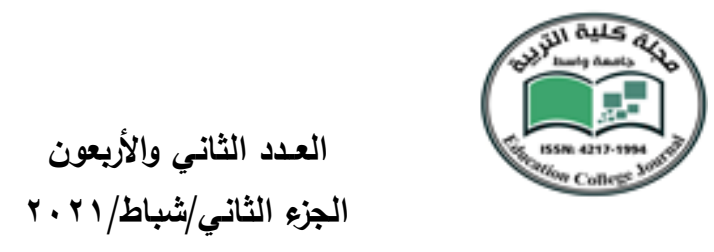

studies , deception expresses transparent symbols of a derived function for language. However deception seems to be used for pro-social and social bonding functions in addition to being applied via human and non-human animal context.

\section{Devices of Manipulation of Meaning}

There are three devices of manipulation of meaning :

\subsection{Essentially Contested concepts}

The notion of 'essentially contested concepts' was presented by the philosopher Gallie (1956). He tried to constitute a list of concepts that are logically different from other kinds of concepts in being always open to contest (Chilton, 2008).

Gallie makes a comparison between these concepts and other types of concepts for which, he adopts, normal argument or proof can constitute definite standards for correct use. Fundamentally, disputed concepts can never be shown in the way he presents. Such concepts can infinitely be both reinforced and disputed by normal arguments of changed kinds, all of them are valid (Gallie, 1956).

\subsection{Deep and Shallow Processing}

It is reasonable to think that even an individual who links a particular lexical item (say, the term 'democracy') with a large amount of conceptual structure may not always, in all circumstances of communication, draw on all of this encyclopedic background knowledge. Chilton (2008:227) uses the expression "Deep and Shallow Processing" and he discovers that one may say that it is not indeed relevant to draw on all the linked background conceptual structure on all the occasions when the term is uttered or understood.

Van Dijk (2008) shows the same phenomenon as 'Precision of Description'. He claims that actors and actions descriptions, social and political events, may differ in many semantic ways. Van Dijk (2008:13) states that "Quite relevant are variations of level or detail with which knowledge is thus communicated, as well as the precision or vagueness of the descriptions". What is called 'Dis-preferred knowledge', for instance, will be left very general, little specific and vague like the state about racism in dominant European discourse genres (political and media discourse). 

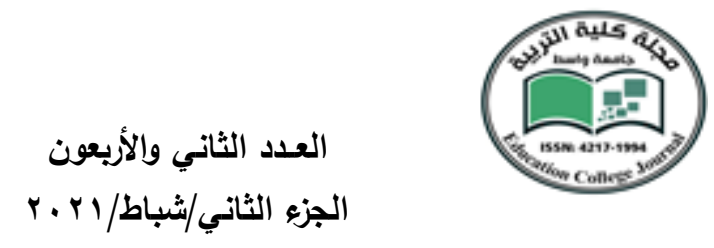

\subsection{Presupposition}

Van Dijk (2008) shows that one of the most important characteristics of discourse is of course "what is not said, but remains implicit"(van Dijk,2008: 27) like the use of presuppositions.

Kadmon (2001) on the other hand, claims that most mutual knowledge is actually presupposed in a text, therefore, it is not certified and even not explained, but left implicit depending on mental models. This means that knowledge may also be 'obliquely' asserted 'accommodated' as if it were generally known and shared. Similarly, clear implications of knowledge which are inconsistent with dominant interests may be left implicit in official discourse. So, the public can merely process some terms used by politicians as good or bad.

\section{Methodology}

There are many types of manipulation that can be discriminated according to the eclectic model, (Malyuga,et al, 2018), (Issers,2008) and (Leontive, 1999) in terms of many criteria:

First, in terms of the nature of subject-object interaction, one can identify direct in which the subject "openly presents his or her claims and demands" and indirect type of manipulation in which "the object is represented not by the recipient per se, but rather by the recipient's medium". (Malyuga, et al, 2018:74).

The direct way of manipulation includes the linguistic forms linked with a static semantic content directly conveying the communicative goal. For instance, the imperative is joined with inducing, narrative and interrogative on the other hand, are joined with "messages and requests for information." Whenever indirect is applied to realize communicative intentions, "the meaning expressed appears to be 'out of touch' with the linguistic forms used." So, indirect does not express the speaker's intention.

Second, in terms of awareness of verbal actions, there are "deliberate (intentional) and inadvertent (non-intentional) manipulation" (Issers, 2008:26). In the intentional verbal manipulation, the subject is looking for a specific result, a scheduled outcome of pre-planned interaction. Whereas in non-intentional verbal manipulation, the results gained are unplanned since 

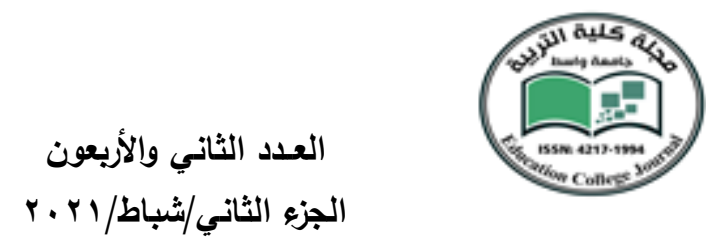

the subject does not originally try to certify any definite communicative outcome.

Third, in terms of the type of speech acts, there are four types of manipulation:

- Social non-informative speech act involving a virtual addressee and cliché utterances, such as greetings, oaths, prayers, etc.

- Volitional speech acts used to impel the speaker to commit an action, such as orders, requests, refusals, advice, etc.

- Informative-explanatory speech acts containing information and its interpretation, such as explanations, reports, confessions, etc.

- Emotional and evaluative speech acts "setting social, moral, legal, interpersonal, subjectively emotional relationships, such as reproach, praise, accusation, insult, threat, etc. " (Shmelev, 1979: 20).

Fourth, in terms of the nature of recipient's response, there are three kinds of verbal manipulation:

- Evaluative, changing the subject's attitude towards the object.

- Emotional, establishing a common emotional state.

- Rational restructuring individual consciousness (Malyuga, et al, 2018:75).

Fifth, in terms of the objective focus of manipulative efforts, there are "person- and group-oriented verbal manipulation" (Leontiev, 1999:66). In person-oriented manipulation, the producer focuses on the recipient by molding the recipient's image so that the desired effect can be achieved. In group-oriented manipulation, "the speaker does not create the image of every single member of the group, but molds a generalized image of the group as a whole in order to secure 'collective' impact."

\section{Data Analysis}

In this section, some extracts are analyzed from two famous reports concerning Golan Heights will be presented concerning the use of manipulation and its types.

\subsection{Analysis of the extracts of CNN report}

Text (1): President Donald Trump on Thursday overturned longstanding US policy regarding the Israeli-occupied Golan Heights, announcing "it is time" for the US to "fully recognize Israel's Sovereignty" over the region. 

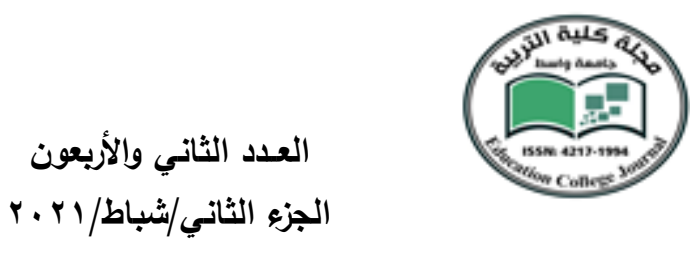

"After 52 years it is time for the United States to fully recognize Israel's Sovereignty over the Golan Heights, which is of critical strategic and security importance to the State of Israel and Regional Stability," Trump tweeted.

$\underline{\text { Analysis }}$

In terms of the nature of subject-object interaction the speaker (Trump) can be considered as a subject and he refers to his demands. So, a direct manipulation is used here. Since the president as a subject shows his wants behind his speech which is represented by stating that the United States recognize Israel's Sovereignty over the Golan Heights.

In terms of awareness of verbal actions, the speech here is intentional that the subject is planned previously to be directed to the recipient.

In terms of the type of speech acts, this text can be considered as informative-explanatory speech acts since there is an explanation represented by showing Israel's level.

In terms of the nature of recipient's response, manipulation here is considered as rational since Trump tries to restructure the people's consciousness.

In terms of the objective focus of manipulative efforts, personoriented manipulation is achieved. In other words, Trump focuses on a definite unity which is Israel.

Text (2): The announcement hands Israeli Prime Minister Benjamin Netanyahu a significant foreign policy victory, less than three weeks before Israelis head to the polls to decide whether he should remain in power. The move comes just days before Netanyahu is set to join Trump at the White House and follows weeks during which Netanyahu has renewed his push for the US to recognize the Golan Heights as part of Israel.

\section{Analysis}

In terms of the nature of subject-object interaction the speaker (Trump) refers to his demands directly. So direct manipulation is used here. Since the president shows his demands behind his speech which are represented by stating that Golan Heights as a part of Israel and referring to Netanyahu reward as having a significant victory. 

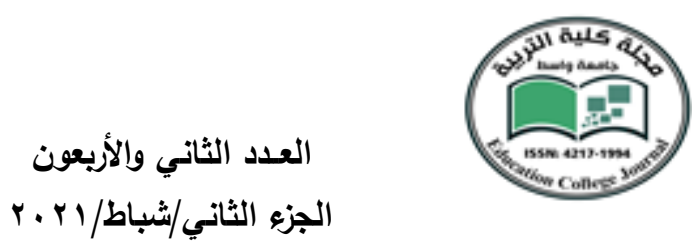

In terms of awareness of verbal actions, the speech here is intentional that the subject is planned previously to be directed to the recipient.

In terms of the type of speech acts, this text can be considered as emotional and evaluative speech acts which is represented by Trump's setting a legal matters concerning the consideration of Golan Heights as a part of Israel.

In terms of the nature of recipient's response, manipulation here is considered as evaluative since Trump changes the attention of the receivers towards the object which is represented by Netanyahu. In other words, Trump turn the receivers' concentration from him as a subject to Netanyahu as an object.

In terms of the objective focus of manipulative efforts, personoriented manipulation is achieved. In other words, Trump focuses on a specific individual who is Netanyahu.

\subsection{Analysis of the extracts of RT report}

Text (1): At a time when Iran seeks to use Syria as a platform to destroy Israel, President Trump boldly recognizes Israeli sovereignty over the Golan Heights. Thank you President Trump! @ realDonaldTrump

Netanyahu had previously urged top US officials to make the declaration and he is expected to meet with Trump at the White House in the coming days. Meanwhile, the Secretary General of the Arab League, Ahmed Aboul Gheit, said that the organization "strongly supports" Syria's sovereignty over the Occupied Golan Heights. Russia also criticized Trump's idea, saying that it is aimed at sowing discord within the Arab world.

\section{Analysis}

In term of the nature of subject-object interaction manipulation is indirect since the object (Netanyahu) is not appeared by himself, but by his medium.

In terms of awareness of verbal actions, the speech here is intentional that the subject is planned previously to be directed to the recipient.

In terms of the type of speech acts, this text can be considered as consisting of emotional and evaluative speech act since emotional 

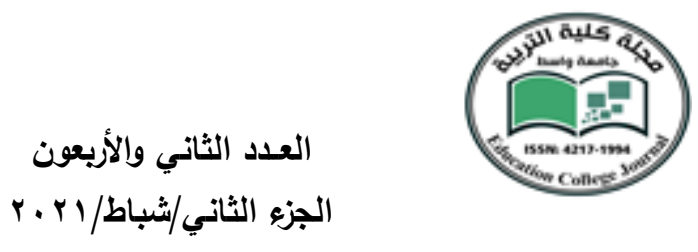

relationships like praising is implied here by the use of Thanking for Trump's effort.

In terms of the nature of recipient's response, manipulation here is considered as evaluative since the producer changes the attention of the receivers towards the object which is represented by Ahmed Aboul Gheit. In other words, the writer turns the receivers' concentration from Netanyahu as a subject to Ahmed Aboul Gheit as an object.

In terms of "the objective focus of manipulative efforts", personoriented manipulation is achieved. In other words, the writer focuses on specific individuals who are Netanyahu and Ahmed Aboul Gheit.

Text (2): The strategically important land is recognized as part of Syria by the United Nations and UN resolutions have called for Israel to withdraw from the areas, as well as other occupied territories, including Gaza and the West Bank.

Trump has consistently backed Israel when it comes to major regional disputes and last year sparked controversy and outrage among Palestinians and others when he moved the US embassy in Israel from Tel-Aviv to Jerusalem and said the US officially recognized Jerusalem as Israel's capital. Analysis

In terms of the nature of subject-object interaction manipulation is direct since the subject shows his demands.

In terms of awareness of verbal actions, the speech here is intentional the subject is seeking a specific result as represented by Israel's backing by Trump.

In terms of the type of speech acts, this text can be considered as consisting of informative-explanatory speech acts since it contains information and explanations concerning Trump's support to Israel.

In terms of the nature of recipient's response, manipulation here is considered as rational which means a restructuring of people consciousness concerning Trump's support to Israel.

In terms of the objective focus of manipulative efforts, personoriented manipulation is achieved. In other words, the writer focuses on a specific individual who is Trump. 


\section{العدد الثاني والأربعون

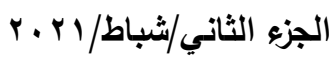

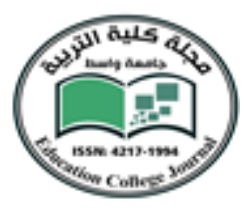

\section{Results and Discussions}

The present study has reached to many results concerning the difference between CNN and RT reports in using manipulation and its types. The following table shows the percentage of each type in the two reports.

Table (1) Percentage of manipulation types in CNN and RT.

\begin{tabular}{|c|c|c|c|c|c|c|c|c|c|c|}
\hline & $\begin{array}{c}\text { the nature of } \\
\text { subject-object } \\
\text { interaction }\end{array}$ & \multicolumn{2}{|c|}{$\begin{array}{c}\text { awareness of verbal } \\
\text { actions }\end{array}$} & \multicolumn{2}{|c|}{ the type of speech acts } & \multicolumn{2}{|c|}{$\begin{array}{c}\text { the nature of } \\
\text { recipient's response }\end{array}$} & $\begin{array}{c}\text { the objective focus } \\
\text { of manipulative } \\
\text { efforts }\end{array}$ \\
\hline $\begin{array}{c}\text { Sub- } \\
\text { type }\end{array}$ & direct & indirect & intentional & $\begin{array}{c}\text { Non- } \\
\text { intentional }\end{array}$ & informative & $\begin{array}{c}\text { Emotional } \\
\text { evaluative }\end{array}$ & rational & evaluative & $\begin{array}{c}\text { Person } \\
\text { oriented }\end{array}$ & $\begin{array}{c}\text { Group } \\
\text { oriented }\end{array}$ \\
\hline CNN & $100 \%$ & 0 & $100 \%$ & 0 & $50 \%$ & $50 \%$ & $50 \%$ & $50 \%$ & $100 \%$ & 0 \\
\hline RT & $50 \%$ & $50 \%$ & $100 \%$ & 0 & $50 \%$ & $50 \%$ & $50 \%$ & $50 \%$ & $100 \%$ & 0 \\
\hline
\end{tabular}

One can notice the big similarity in the use of manipulation and its types in both reports produced by $\mathrm{CNN}$ and RT. The only difference between them is in terms of the nature of subject-object interaction that $\mathrm{CNN}$ uses direct $100 \%$ while RT uses direct and indirect manipulation equally $50 \%$.

After analyzing these two reports, one can notice how the reports tend to use manipulation in most of its texts. The first report by CNN tends to use manipulation directly represented by Trump's speech.

The CNN report provides a positive opinion of Trump towards Netanyahu. The second report provides a neutral speech concerning Golan Heights. It focuses on both Israeli and Arabic roles in getting Golan Heights.

\section{Conclusions}

The present study concludes that manipulation is a linguistic term with great creative potential that is first and foremost topical in the framework of the theory of linguistic manipulation. Manipulation is divided into five main types according to: the nature of subject-object interaction, awareness of verbal actions, the type of speech acts, the nature of recipient's response and the objective focus of manipulative efforts. In addition to that, political reports tend to use manipulation in most of its texts in order to get the readers' focus to something that they consider as important. Moreover, there 

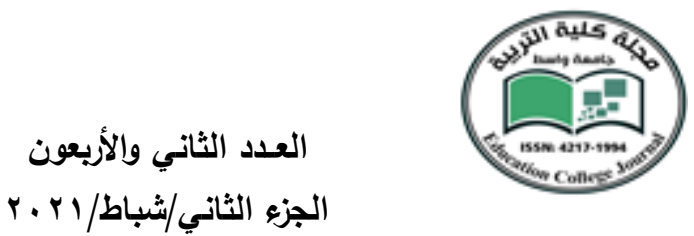

is a great similarity in the use of manipulation and its types in both reports produced by CNN and RT. The only difference between them is in terms of the nature of subject-object interaction that $\mathrm{CNN}$ uses direct $100 \%$ while RT uses direct and indirect manipulation equally $50 \%$.

\section{References}

Asya, R. (2017). Linguistic manipulation: definition and types.

University of Rostov.

Blass, R. (2002). Manipulation in the speeches and writings of hitler and the NSDAP. Paper delivered at the International Conference on Manipulation in the Totalitarian Regimes of the Century, Ascona, Switzerland.

Beard, A. (2000). The language of politics. London: Routledge.

Chilton, Paul (2008). Political terminology. Berlin: Walter de Gruyter.

Van Dijk, T. (1989). Language, perception, communication. Moscow: Progress.

Gallie, Walter B. (1956). Essentially contested concepts. Proceedings of the aristotelian Society 56: 167- 198.

Issers, O.S. (2008). Communicative strategies and tactics of russian speech. Moscow: URSS, LKI.

Kadmon, N. (2001). Formal pragmatics. Semantics, pragmatics, presupposition, and focus. Malden Oxford: Blackwell.

Leontev, A.A. (2005). Word in speech activity. Moscow, 2005.

Levin, R, McCornack, A.(2014). Theorizing about deception. Journal of language and social psychological.

Malyuga, E.N. etal (2018) Linguistic pragmatics of intercultural professional and business communication. Switzerland: Springer

Oesch, N. (2016). Deception as a derived function of language. Frontiers in Psychology journal. Published online on 2016 Sep 27.

https://www.frontiersin.org/article/10.3389/fpsyg.2016.01485

International Publishing AG.

Pelz, J. (1981). Theoretical foundations of semiotics, American Journal of Semiotics 1.1-2, 15-45 . (1982). Semiotic and non-semiotic concepts of meaning, American Journal of Semiotics 1.4, 1-19. 